\title{
A NEW SMALL-FLOWERED NATURAL ODONTOGLOSSUM HYBRID (ORCHIDACEAE: ONCIDIINAE) FROM ECUADOR
}

\author{
Stig Dalström ${ }^{1,3} \&$ Wesley E. Higgins ${ }^{2}$ \\ 12304 Ringling Boulevard, unit 119, Sarasota FL 34237, USA; Lankester Botanical Garden, \\ University of Costa Rica, Cartago, Costa Rica; National Biodiversity Centre, Serbithang, Bhutan \\ ${ }^{2}$ Lakes Park Botanic Garden, Fort Myers, Florida; 5317 Delano Court, Cape Coral, Florida 33904, U.S.A. \\ ${ }^{3}$ Corresponding author: stigdalstrom@gmail.com
}

\begin{abstract}
A new small-flowered natural Odontoglossum hybrid from northwestern Ecuador is described and illustrated with a line drawing and a photograph. The novelty is compared with its sympatric parent species, Odontoglossum armatum and O. mirandum. The flower of the new natural hybrid has shorter erect lateral liplobes compared to those for $O$. mirandum, but distinctly longer erect lateral lip-lobes compared to those for $O$. armatum, which are basically lacking altogether. The taxonomic status of the variable $O$. mirandum is briefly discussed.
\end{abstract}

KeY wORDS: Ecuador, new hybrid, Odontoglossum, Orchidaceae, Oncidiinae

During some extensive work by author Dalström in the herbarium of the Marie Selby Botanical Gardens, Sarasota, Florida (SEL), several decades ago, a dried specimen of an Odontoglossum Kunth was found that showed some morphological features that deviated from all known species in the genus. These features were intermediate between the sympatric $O$. armatum Rchb.f. (Fig. 1A), and O. mirandum Rchb.f. (Fig. 1B-C), and it was concluded at the time that this particular specimen, mounted on sheet 025039 (SEL) together with a specimen of $O$. armatum, represents an undescribed natural hybrid. This plant was collected by Carlyle and Jane Luer of Sarasota, Florida, together with Alexander Hirtz of Quito, Ecuador, in a cloud forest above the small town of Maldonado (Fig. 2) in the Carchi province of Ecuador, at ca. 2000-2500 m elevation, in August of 1978.

The taxonomic status of Odontoglossum versus Oncidium Sw., has been debated for many years and can be studied more closely in other publications (Chase et al. 2008, Dalström 2012, Dalström \& Higgins 2016, Neubig et al. 2012, Dalström \& Higgins in press). The authors of this paper argue that the transfer of Odontoglossum, together with genera Cochlioda Lindl., Collare-stuartense Senghas \& Bockemühl, and Solenidiopsis Senghas, which were all subsequently transferred to Odontoglossum (Dalström 2012), and Sigmatostalix Rchb.f., was unnecessary and does not improve the complex Oncidiinae taxonomy. In addition, no diagnostic keys or explanations of how to define the enlarged genus Oncidium was ever provided. The primary argument for implementing the transfer resulted from a failure to distinguish Odontoglossum from Oncidium based on flower morphologies: "If Odontoglossum is to be maintained as a distinct genus, then many more genera will need to be created or some long-known species with typical Oncidium floral morphology (e.g., O. chrysomorphum Lindl., O. obryzatum Rchb.f.) will have to be transferred into Odontoglossum, which removes any hope of morphological distinctiveness for Odontoglossum." (Chase et al. 2008). Yet, a major subsequent argument advanced in a defense for making the transfer suggest that we should base Oncidiinae taxonomy on vegetative features rather than floral features: "We feel that it is better to use vegetative features in combination with few floral traits to define broader genera... Oncidium is perhaps the best example of our contention that floral morphology must be foregone in Oncidiince as a basis for generic characters... Floral traits in Oncidiince are highly plastic and reflect evolutionary shifts in pollinators." (Neubig et al. 

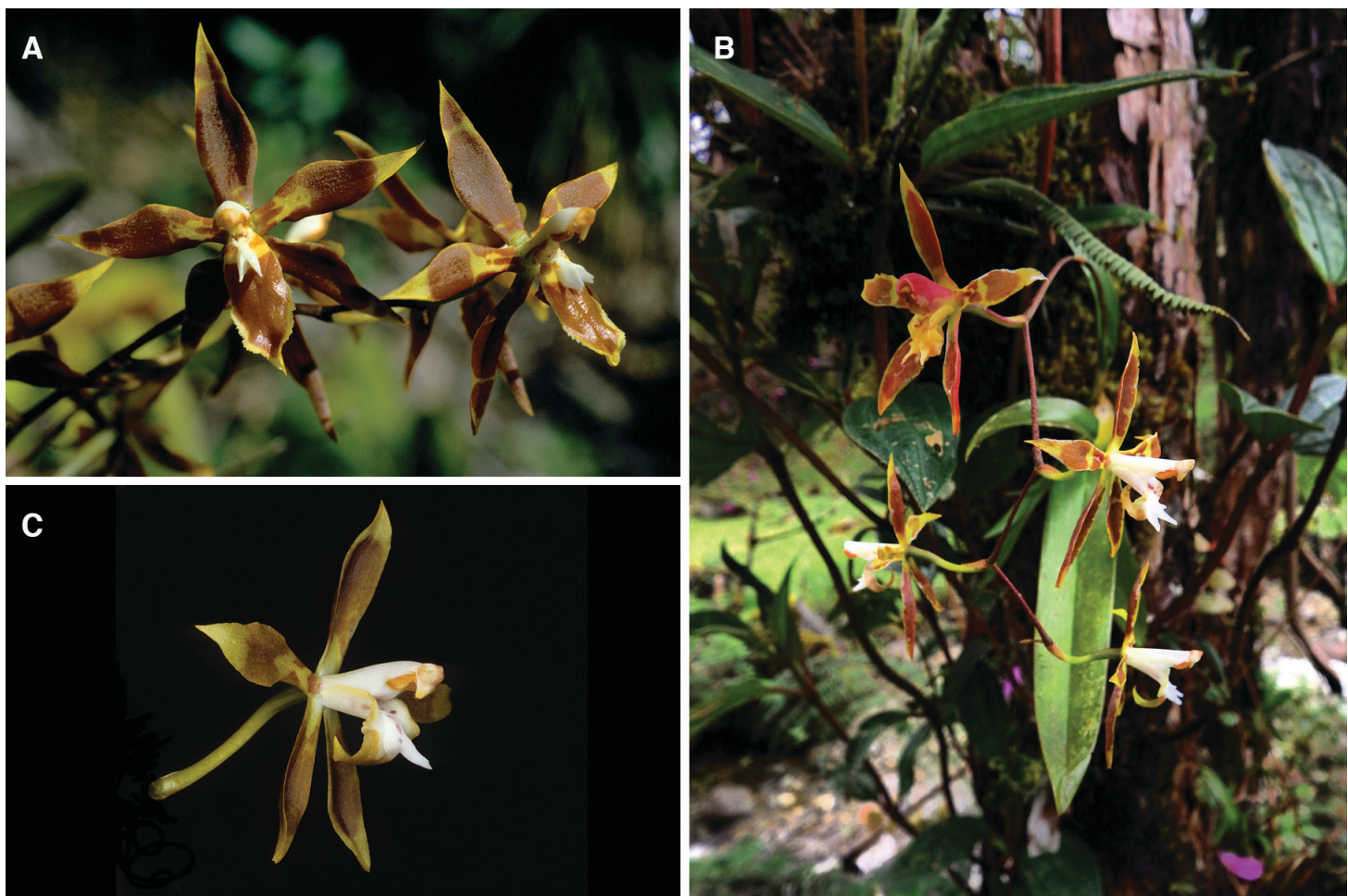

FIgURE 1. A - Odontoglossum armatum, growing lithophytically at $c a .2500 \mathrm{~m}$ elevation along the road from Tulcan to Maldonado in the Carchi province of Ecuador. B - Odontoglossum mirandum ("reversum"), growing epiphytically in wet cloud forest in the Sibundoy area, Putumayo, Colombia. C - Close-up of a flower of Odontoglossum mirandum ("reversum") growing epiphytically at ca. 2200-2500 m elevation in wet cloud forest on the eastern slopes of the Andes near the town of La Bonita, Sucumbíos, Ecuador. This small-flowered form of $O$. mirandum also occurs sympatric with $O$. armatum on the western slopes of the Andes where the type of $O$. x luerorum was discovered. Photographs by Stig Dalström.

2012). By examining vegetative features of the species with "Oncidium-looking" flowers mentioned by Chase et al. above we have found it relatively easy to distinguish those species by a rather basic combination of vegetative and floristic features, which in addition to molecular evidence in fact support the transfer of those species into a slightly enlarged genus Odontoglossum (Dalström 2012, Dalström \& Higgins 2016). We also believe that the considerable historic and horticultural importance of Odontoglossum support preserving the genus' validity. It also saves us from creating "many more genera".

One of the parent species of the new natural hybrid described in this paper has a somewhat complicated taxonomic background, which is briefly discussed here. Leonore Bockemühl (1986) described a small-flowered form of O. mirandum from San Francisco, Putumayo, in southern Colombia, as Odontoglossum reversum Bockemühl. But when the natural variation in size and shape of this taxon is taken into consideration there is nothing significant that consistently distinguish it from the highly variable $O$. mirandum other than the smaller size. They are therefore treated as con-specific by us at this time. Bockemühl described a plant from the same geographic area as where the natural hybrid described here comes from as Odontoglossum lindleyanum Rchb.f. \& Warsc. var. parviflorum Bockemühl (1989). This plant also corresponds morphologically very well with other small-flowered forms of $O$. mirandum (as well as for "O. reversum") and it is concluded by us that they are conspecific. A plant that carried flowers with unusually short sepals and petals flowered in December of 1884, at the New Plant and Bulb Company, Colchester, UK, and was sent by the owner 


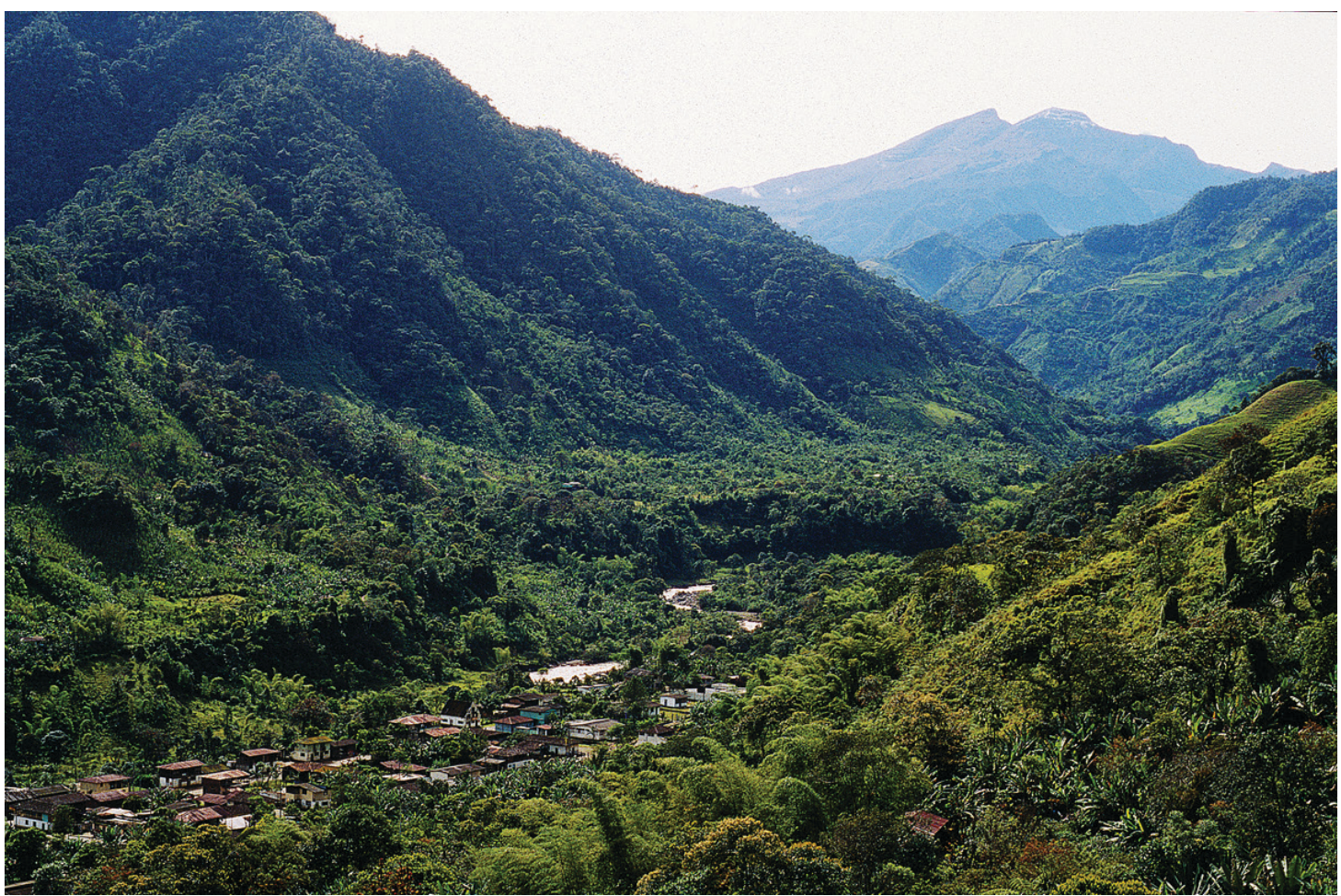

FIgURE 2. The town of Maldonado on the western slopes of the Andes, Carchi, Ecuador, where many new orchid species and natural hybrids have been discovered over the years. Photograph by Stig Dalström.

Alexander Wallace to Heinrich Gustav Reichenbach in Hamburg, Germany, who described it as O. mirandum var. breve in the same year (Reichenbach 1884). There is nothing that significantly separates this latter taxon from the variable $O$. mirandum either, so they are all treated here as representing the same species.

\section{TAXONOMIC TREATMENT}

Odontoglossum $\times$ luerorum Dalström \& W.E.Higgins, hybr. nat. nov.

TYPE: Ecuador. Carchi, epiphytic in cloud forest above Maldonado west of Tulcan, alt. 2000-2500 m, 25-25 Aug. 1978, C. Luer, J. Luer \& A. Hirtz 3373 (holotype: SEL). Fig. 3-4.

Diagnosis.- Odontoglossum $\times$ luerorum is visually similar to both $O$. armatum and $O$. mirandum but differs by its intermediate features, such as having erect lateral lip lobes that are distinctly shorter, $c a$. 2.5-3.0 $\mathrm{mm}$ long versus ca. $7 \mathrm{~mm}$ long for $O$. mirandum, but distinctly longer than for $O$. armatum, which basically lack erect lateral lip-lobes altogether and where the lip is fused to the column by lateral flanks only, as opposed to a short central longitudinal ridge (as for $O$. mirandum), combined with lateral flank fusion for $O$. $\times$ luerorum.

Epiphytic herb. Pseudobulb caespitose, ovoid and longitudinally wrinkled with age, basally sparsely spotted with purple, unifoliate, ca. $3.5 \times 1.2 \mathrm{~cm}$, surrounded basally by 5 to 6 distichous sheaths, the uppermost foliaceous. Leaf petiolate and conduplicate, petiole $c a .3 .5 \mathrm{~cm}$ long and blade $c a .9 \times 1.0-1.1 \mathrm{~cm}$, narrowly elliptic and acute. Inflorescence axillary from the uppermost sheaths, erect to arching, threeflowered, almost straight to indistinctly flexuous, to ca. $19 \mathrm{~cm}$ long raceme; bracts appressed, scale-like and acute, to ca. $5 \mathrm{~mm}$ long. Flowers stellate; dorsal sepal yellow with brown spots and markings, elliptic, acute, ca. $25 \times 7-8 \mathrm{~mm}$; lateral sepals similar in color, indistinctly spathulate, slightly obliquely ovate and acuminate, $c a .27 \times 6 \mathrm{~mm}$; petals similar in color but with a white base, broadly unguiculate to almost 


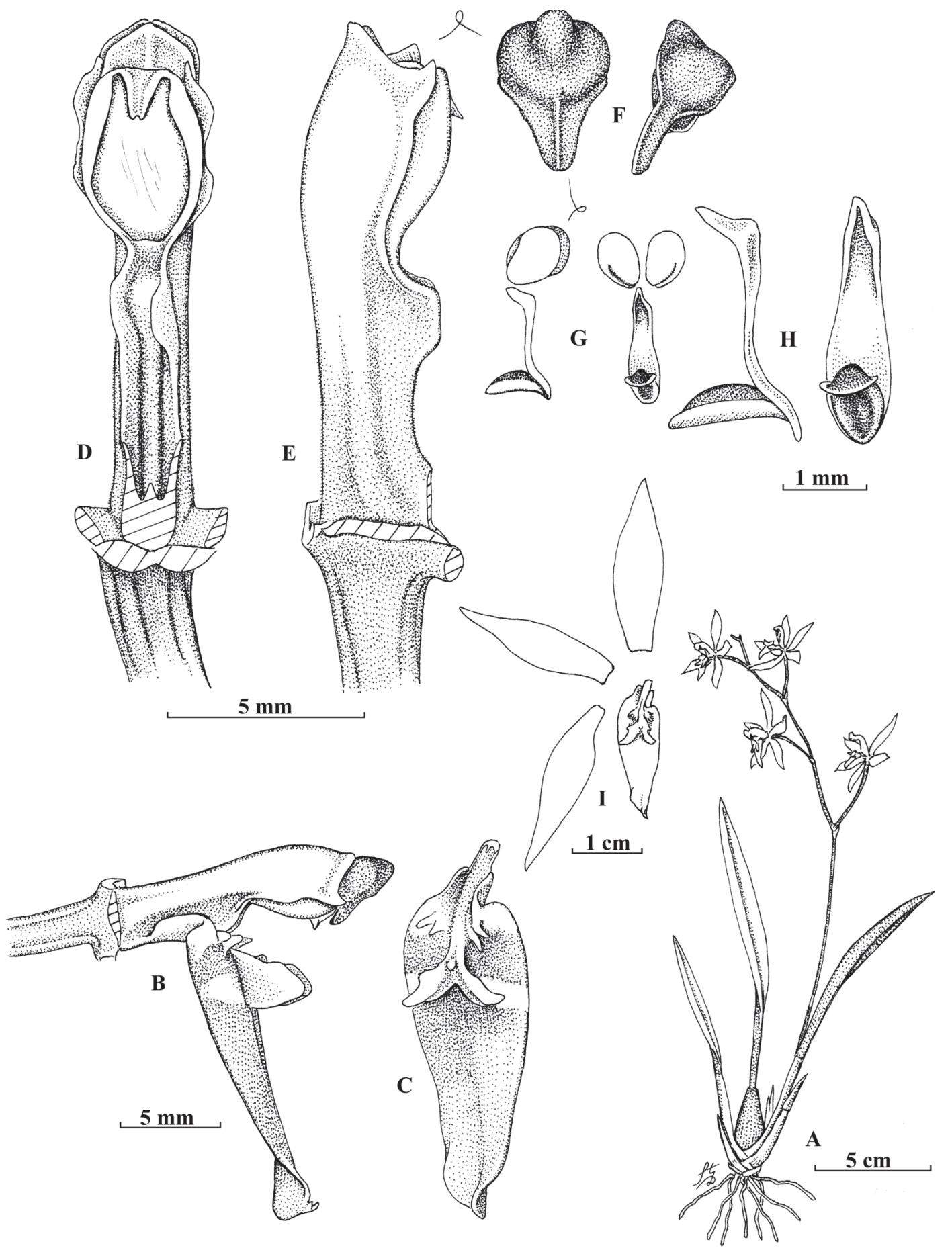

FiguRE 3. Odontoglossum x luerorum Dalström \& W.E.Higgins. A. Plant habit. B. Column and lip lateral view. C. Lip dorsal view. D. Column ventral view. E. Column lateral view. F. Anthercap dorsal and lateral views. G. Pollinaria lateral and back-views. H. Stipe and viscidium lateral and back-views. I. Flower dissected. Drawn from the holotype (SEL) by Stig Dalström. 


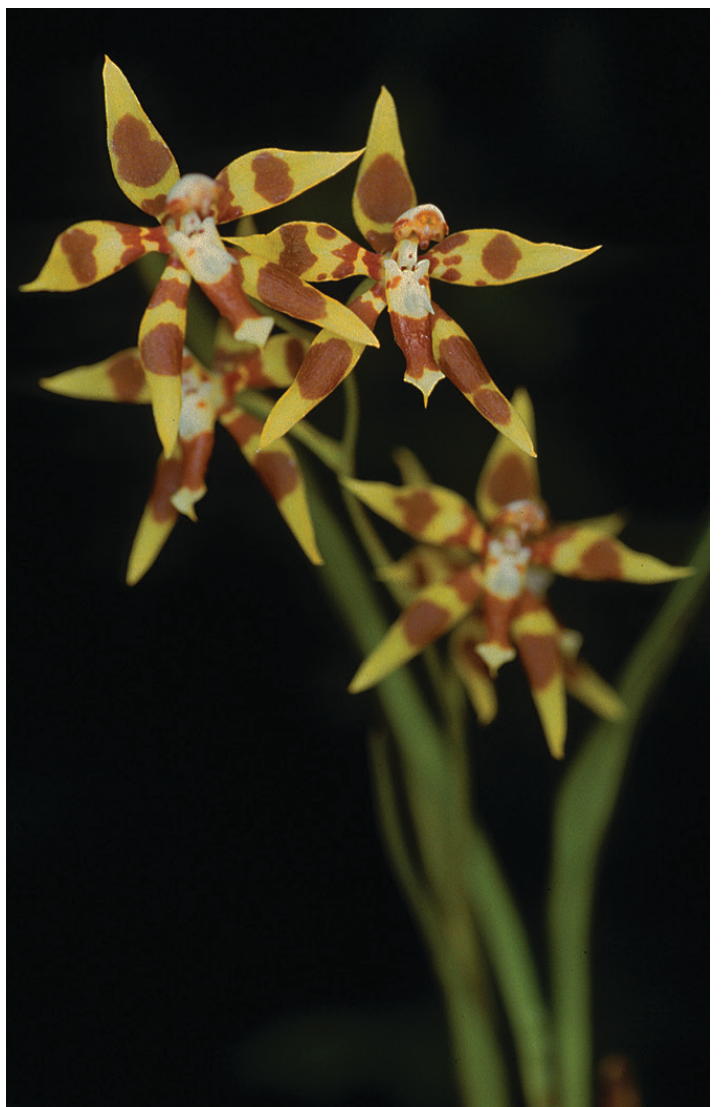

FIgURE 4. Odontoglossum x luerorum, collected in the same area as the holotype, cultivated and photographed by Stig Dalström. Not the same plant as the type specimen, and no preserved specimen was ever made.

sessile, indistinctly obliquely ovate, acuminate, $c a .24$ $\times$ 6-7 mm; lip basally white then with a brown band, followed by a white band and a brown front lamina, rigidly attached to the base of the column through an indistinct, minute central ridge and by the lateral ventral flanks of the column for $c a .2 .5 \mathrm{~mm}$, then free developing into erect lateral side-lobes for $c a$. 2.5-3.0 $\mathrm{mm}$, then angled downwards into a narrowly cordate, entire, apically weakly canaliculated, $c a .15$ $\times 5-6 \mathrm{~mm}$ lamina; callus of a fleshy, central ridge emerging from the base of the lamina, developing into a pair of large, bluntly angular, horizontally flattened spreading keels, with a small knob in between and a pair of spreading much smaller digitate keels on each side basally; column clavate, almost straight but indistinctly curved towards the lip near the apex, canaliculated ventrally with distinct lobes beneath the stigma, with a pair of indistinct forward projecting acute angular winglets, $c a .12-13 \mathrm{~mm}$ long; anther cap campanulate, distinctly rostrate with a narrow ridge along the "beak", and dorsally lobulate; pollinarium of two folded/cleft ovoid pollinia on a narrowly elongate triangular, apically curved and angular, $c a$. 2.8-3.0 $\mathrm{mm}$ long stipe on a ovoid pulvinate and curved viscidium.

PARATYPE: Ecuador. Carchi, same area as the holotype, collected at $c a .2500 \mathrm{~m}$, and flowered in cultivation, $S$. Dalström s.n. (color transparency, Dalström archives, Fig.6. This is not the same plant as the holotype!).

Distribution: The distribution of Odontoglossum $\times$ luerorum is so far only reported from northwestern Ecuador where it occurs as an epiphyte at relatively high elevation cloud forest.

Eponymy: Named in honor of Carlyle A. and Jane H. P. Luer of Sarasota, Florida, in gratitude for providing monumental amounts of ground-breaking orchid taxonomic knowledge and literature.

ACKnowledgments. The authors thank the herbarium curator and administration at the Marie Selby Botanical Gardens for allowing studies of preserved orchid specimens.

\section{LiTERATURE CITED}

Bockemühl, L. (1986). Odontoglossum reversum. Orchidee (Hamburg), 37, 207.

Bockemühl, L. (1989). Odontoglossum, a Monograph and Iconograph. Hildesheim, Germany: Brücke-Verlag Kurt Schmersow.

Chase, M. W., Williams, N. H., Neubig, K. M. \& Whitten, W. M. (2008). Taxonomic transfers in Oncidiinae to accord with Genera Orchidacearum, vol. 5. Orchids, $77,20-31$

Dalström, S. (2012). New combinations in Odontoglossum (Orchidaceae: Oncidiinae) and a solution to a taxonomic conundrum. Lankesteriana, 12(1), 53-60

Dalström, S. \& Higgins, W. E. (2016). New combinations and transfers to Odontoglossum Oncidiinae (Orchidaceae): avoid creating new names. Harvard Papers in Botany, 21(1), 115-122.

Dalström, S. \& Higgins, W. E. (in press). A monophyletic Odontoglossum. The Proceedings of the 22 $2^{\text {nd }}$ World Orchid Conference. Guayaquil, Ecuador.

Neubig, K. M., Whitten, W. M., Williams, N. H., Blanco, M. A., Endara, L., Burleigh, J. G., Silvera, K., Cushman, J. C. \& Chase, M. W. (2012). Generic recircumscriptions 
of Oncidiinae (Orchidaceae: Cymbidieae) based on maximum likelihood analysis of combined DNA datasets. Botanical Journal of the Linnean Society, 168, $117-146$.
Reichenbach, H. G. (1884). Odontoglossum mirandum var. breve. New Garden Plants. Gardeners Chronicle, 22(573), 776. 